\title{
Estimating Stream Discharge of Aboine River Basin of Southeast Nigeria using Modified Thornthwaite Climatic Water Balance Model
}

\section{${ }^{* 1}$ EZEMONYE MN; ${ }^{2}$ EMERIBE CN; ${ }^{3}$ ANYADIKE R. NC}

\author{
${ }_{1}$ Department of Geography and Regional Planning, University of Benin, Benin City, Edo State, Nigeria \\ ${ }_{2}$ National Centre for Energy and Environment, University of Benin, Benin, City, Edo State, Nigeria \\ Department of Geography, University of Nigeria, Nsukka, Enugu State (***Late) \\ *Corresponding authors address E-mail: ezemonyemary@yahoo.com; +2348033418529
}

\begin{abstract}
The study attempts to estimate the stream discharge of the Aboine river basin, southeast Nigeria, using modified climatic water balance approach. Moisture deficit in the basin generally begins from January and lasts up to April while utilization begins from October up to December. The basin attains a field capacity from August to September and decreases in moisture storage from October when more water is removed from the basin to meet plant water needs. The value of the circularity ratio of 0.29 showed that the Aboine Basin will produce little surface runoff. Results of bifurcation ratio, compactness coefficient, stream length and modeling of inter-basin parameters showed that the Aboine drainage basin is basically a flat surface. This will affect both the amount of water available from the basin for any water resources projects. Such information also provides the basis for demonstrating the effects of environmental control on the fluvial system and also for predicting the basin output variables. Surface runoff contribution to discharge was computed as a residual of our modified climatic water balance equation while groundwater flow contribution to discharge was determined from the separation of water stage hydrograph available for the study area from 1984 to 1987, using the hydrograph separation technique. Comparison of calculated discharge values using modified THWB climatic water balance with stream discharge determined from water- stage showed significant difference between computed stream discharge from water stage and discharge estimated from our water balance model at 0.05 level of confidence. This suggests that our modified water balance model if further improved maybe suitable for generating information on all the aspects of the moisture relationship in the basin in the absent of measured stream flow data. (C) JASEM http://dx.doi.org/10.4314/jasem.v20i3.30
\end{abstract}

Key word: Stream discharge, basin morphometry, surface flow, groundwater flow, water resource

Faced with these challenge, it has becomes necessary to resort to alternative methods for estimating discharge data for ungauged basins, including extrapolation of streamflow records from the nearest, similar gauged catchment; regression-based techniques (usually employing climatic and drainage basin explanatory variables as part of a Regional Flood Frequency Analysis); and more sophisticated, physically-based hydrological models. The choice of method for any method will depend upon the quality and range of available data, the nature and accuracy required of the discharge estimates, and the time and cost constraints of the exercise (Wharton and Tomlinson, 1999). In Nigeria, the method of data extension has always been employed (Sule, et al, 2011; Sobowale et al,. 2010). The principles of this technique involve correlating the short or inadequate records with large records of nearby stations or adopting the rainfall-runoff data extension method. The correlation can be done with mean annual, mean monthly, mean daily or instantaneous discharges. The confidence in data generated by this correlation technique depends on the physical and climatic characteristics of the basins being considered, for they would have to be homogeneous. Moreover, this condition of basin homogeneity is often hardly met which often results in failure of many water resources projects to meet demands.

The provision of missing data by correlation, projections based on hydrological data from other but climatologically similar places are mere approximations that may fail in accuracy, hence they mostly depend on chance (Dike and Nwachukwu 2003, Ezemonye and Emeribe, 2013). The other method is by understanding and measuring of the fundamental processes involved in the hydrological events based on the principle of hydrological balance. The processes relates of course to the components of the hydrological cycle (precipitation, evaporation, infiltration etc). In using the water balance technique for estimating basin discharge, it has been discovered that the method not only detects easily individual error of measurements, but also enhances the 
understanding of relationships of physical processes in drainage basins (Pohle. et al, 2012; Eruola et al. 2012). In addition, using water balance technique for appraising the water resources of drainage basin represents some improvements over the simple rainfall-runoff relationships (Ayoade, 1998). Xu and Singh, (1998) further showed that using water balance technique for estimating stream discharge for ungauged basins is attracting a wide range of interest and more so is frequently applied in several fields such as for reconstruction of the hydrology of catchments, assessment of climatic change impacts and evaluation of the seasonal and geographical patterns of water supply and irrigation demand. For integrated and sustainable water resource management, it is essential to understand water balance of river basin (Matsuyama et al., 1994). The present study therefore aims at modelling the stream discharge of the Aboine basin using the water balance technique, with a view to ascertaining the accuracy of the method for estimating the stream discharge of ungauged river basin, in southeast Nigeria.

\section{MATERIALS AND METHOD}

Study area: The Aboine river drainage is located between Enugu and Ebonyi States of south-eastern Nigeria. It lies between latitudes $5^{\mathrm{O}} 44 \mathrm{~N}$ and $6^{\mathrm{O}} 55^{\prime} \mathrm{N}$ and longitudes $7^{\mathrm{O}} 25^{\prime} \mathrm{E}$ and $8^{\mathrm{O}} 02^{\prime} \mathrm{E}$. The basin is a $7^{\text {th }}$ order basin according to the system of stream network classification developed by Strahler (1952). The area of the basin is approximately $3,645.38 \mathrm{~km}^{2}$. The major rivers in the study area include the Nyaba, Idodo, Iyako, Ora and Ata-for rivers which serve as important sources of water supply for the inhabitants of the study area. The Ora River and its tributary form the headwater of the Aboine basin. Generally, the Aboine basin flows in a north-east direction and empties into the Cross river basin (Fig. 1). The study area comprises seven geological formations and mostly sedimentary rocks (Orajaka, 1975) These include the Asu River Group, Eze-Aku Group, Nkpro Shales, False Bedded Sandstones, Lower Coal Measures, Awgu Sandstones and the Awgu-Ndeaboh Shales. These rocks are essentially of low permeability and generally run in stripes from NorthWest to South-East. Generally, the Aboine river basin falls within two physiographic regions. These are the Nsukka-Okigwe Cuesta and the Cross River Plains. The Nsukka- Okigwe Cuesta is formed by the more resistant sandstones and siltstones in the Lower Coal Measures and the lower part of the False-Bedded Sandstones (Ofomata, 1975). The Cross River Plains on the other hand are underlain by folded argillaceous sediments and consist essentially of an undulating low land region, the greater part lying between 50meters to 100 meters above sea level.

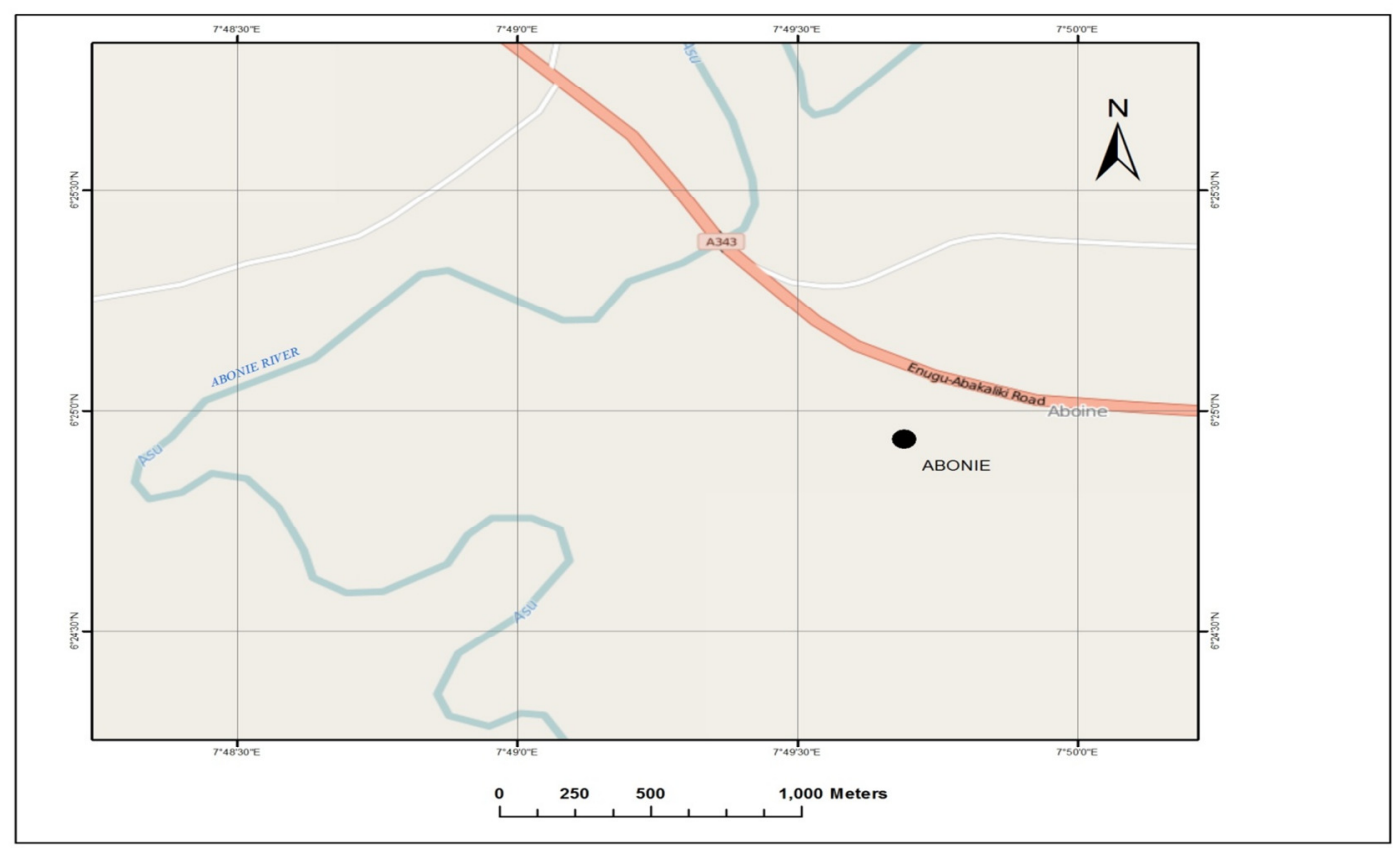

Fig.1: Aboine River Basin 
The study area has a tropical wet and dry climate and exhibits definite wet and marked dry seasons in response to the apparent movement of the sun. Rainfall in the study area essentially depends on the interaction of two major air masses viz: the Tropical Continental (cT) and Tropical Maritime (mT), and they both meet at the Inter-Tropical Discontinuity (ITD). The annual rainfall totals for the study area range from $1450 \mathrm{~mm}$ to $1900 \mathrm{~mm}$, with August having the heaviest rainfall value. Thus, rainfall pattern in the study area is a good reflection of the seasonal variations of the surface location of the inter-tropical discontinuity (ITD) (Anyadike, 2002). The rainy season spans from April up to October, while the dry season last from November to March. Temperature values in the basin are relatively high, with mean annual temperature ranging from $26^{\circ} \mathrm{C}$ and $30^{\circ} \mathrm{C}$, with the highest temperature being experienced from February to April.

Data Collection : The data used in the study include water stage, rainfall, and temperature data. Others are basin morphometric data. Climatic data were collected for the periods from 1984 to 1987 from the Nigeria Meteorological Agency, Oshodi, Lagos State. In a study involving modelling of process - response relationships such as this, it is required that climatic data are collected for the same period for which there are discharge or water stage data. Though these data may appear old for investigation of process-response relationship in drainage basin, Adejuwon et al (1983) have shown that in geographic analysis what is of importance is the difference in spatial association and variation from place to place and not necessarily over time.

In this study, stream discharge was determined as the sum of surface runoff from precipitation and contribution from groundwater flow. Surface runoff of the study area for the period of study (1984 -1987) was estimated as the residual of our modified water balance equation while groundwater flow contribution to stream discharge was determined by separating the hydrograph of the water stage available for the study area into surface and groundwater flows. This was done using the graphical method of hydrograph separation. The choice of the study periods derives from the fact that the period 1984-1987 is the latest periods for which data on water stage are available.

Water Stage Data: Data on water stage were collected from the Awkunanaw stream gauging station. These data were collected from the AnambraImo River Drainage Basin Development Authority
(A.I.D.B D.A). Water stage is the measure of the stream surface height in metres and are usually monitored by means of a staff gauge and then converted into actual discharge using the rating curves for the respective basins. The rating curves are in form of graphs and equations and are published alongside the gauge height records in hydrological year books. From the hydrological records on the study area which is available from the hydrological year book no effort was made by the A.I.D.B.D.A to convert the water stage to actual discharge. However, bearing in mind the aim of this study and also owing to the fact that stream discharge is the sum of direct flow and groundwater contributions, the available information on water stage were used to determine the contribution of groundwater flow to discharge for the periods of study. It follows thus that if the amount contributed by groundwater flow to stream discharge is known, stream discharge becomes the sum of monthly groundwater contribution and calculated monthly surface runoff.

Estimation of Surface Runoff : The basic elements of the water balance equation include precipitation, evapotranspiration, runoff and change in soil moisture storage. Frantar et al (2008) gave the water balance equation as thus;

$P=Q+p E T+\Delta s t$

Where;

$\mathrm{P}$ is Precipitation,

Q is Runoff,

PET is Potential evapotranspiration

$\Delta \mathrm{St}$ is Change in soil moisture storage

From equation 1, the total amount of water available to a basin is equal to runoff plus the evapotranspiration from soil and storage. The latter can be seen as a form of ground water recharge. In the equation however there is assumed to be no direction of inflows or outflows of water from the basin. It is therefore our aim to modify the water balance equation to develop a surface runoff simulation model indicating directions of inflow and outflows of rainwater from the basin as has been done by other researchers (Frantar et al, 2008; Hugh and Ayers, 1970). Evapotranspiration component of the equation was determined using Thornthwaite (Thornthwaite, and Mather (1955). Consequently, our modified water balance equation is then given as; $Q=P-p E T-\Delta s t$

Where Q, P PET and $\Delta$ St are as in equation (11) 
Since the principle of the water balance equation is based on only precipitation, evapotranspiration and depth of soil moisture storage, equation (2) did not reflect the effects of basin surface characteristics on infiltration/surface runoff generation processes, hence we made a bold step to include the runoff coefficient "C" in equation (2). The runoff coefficient ' $C$ ' represents the effects of basin surface characteristics on surface runoff generation process. Following this, our working surface runoff simulation model is given as

$Q=P-p E T-\Delta s t(c)$

Where $\mathrm{C}$ is the surface runoff coefficient, $\mathrm{P}$ and PET are as in equation (1), $\Delta \mathrm{St}(\mathrm{C})$ is potential moisture storage.

The effect of basin factors which is represented by 'C' was empirical estimated using the Rantz (1971) method which varies from one ecological zone to another. The Aboine basin falls within runoff coefficient value of (0.35) which is loam and gravely soils and without impending horizons (i.e porous layers).

Mophormetric Parameters of the Basin: The morphometric and geometric properties of the basin used for the study were computed from topographic maps of scale 1:50000 covering the entire basin. For the entire basin area, fourteen topographic sheets were used. These are Nsukka NE and SE, Igumale NW, SW and SE, Udi NE, SE, Nkalagu NW, NE, SE, SW, Abakalike NW, SW, Afipko NE. These maps were assembled from the Cartographic Laboratory of the Department of Geography, University of Nigeria, Nsukka. Although there are a lot of problems associated with using topographic maps for extracting morphometric indices such as the problems of map accuracy, scale and stream representation, researches have shown that using topographic maps of scale 1:50000 minimizes some of these problems, is time saving and is economical when compared to direct field measurements (Morisawa, 1957; Ebisemiju, 1976).

\section{Analyses of Stage-Discharge Relationship: Discharges occurring between periods of measurements are determined from stage - discharge curves. Stage is the water surface above a selected arbitrary datum plane. As noted earlier the rating curves of our study area which come in form of graphs are not provided in the Hydrological Year Book. Consequently, we employed the empirical}

method involving equations. Gray (1970) observed that flow measurement structures are constructed in channels to ensure a constant stage-discharge relationship and to provide accurate discharge measurements without the use of velocity measurements. In this regards, the only field measurements required are measurements of stage. Measured stage may then be converted into discharge using a rating curve equation. Accordingly, Ayoade (1988) noted that a theoretical but stable relationship between stage (depth of water) and discharge for a particular control structure is usually established so that values of discharge can be computed from known values of stage. Two main types of flow measuring or control structures are weirs in which the water flows over and flumes in which the water flows through the flow measuring structure. Gray (1970) observed that these structures can be calibrated and used for discharge measurement. Stage records of our study were obtained using the weir structure. Studies have given the rating curve equation of a $90^{\circ}$ sharpcrested flow measurement structure which is usually used in small basins. According to Gray (1970) and Ayoade (1988), the equation is given as;

$$
Q=1.38 H^{2.5}
$$

Where $\mathrm{Q}$ is discharge in Cusecs

$H$ is stage in meter and 1.38 is the discharge coefficient of a sharp-crested weir control structure.

The coefficient of discharge in the equation is a function of the friction loss due to the weir, the amount of vertical and horizontal contractions of flow, the effects of adherence and coherence, and the form of the weir structure (Gray, 1970).

Data Analysis: Statistical techniques used in the study include the regression analysis to generate models of intra-basin parameters relationships such as relationships between stream number and order. The water budget bookkeeping procedure was used to compute the values of evapotranspiration, moisture deficit, surplus, moisture storage and changes in storage. Tables, graphs, maps and equations are used where necessary to compute and present the results of various analyses. Some of these graphs were generated using computer programmes such as Microsoft Excel.

\section{RESULTS AND DISCUSSION}

Stream ordering is a classification which reflects the degree of branching and bifurcation within a drainage basin. Stream ordering is considered fundamental to 
any numerical analysis of drainage basin characteristics due to the different morphometric and hydrologic features associated with each basin (Suresh 2000; Guarnieri and Pirotta, 2008). Strahler (1952) ordering system which has a genetic basis and allows for comparative analysis of drainage basins was adopted in this study.

It can seen that the relationship between stream numbers and basin order, stream network arrangement (Bifurcation ratio) in the study area conforms well with the Horton's first law of stream number, that the number of stream segments of different basins decrease with increasing order and vice versa (Table 1). The sum of the entire bifurcation ratios in the study area was divided by the total number of bifurcation ratios. This gives the average bifurcation ratio of the study area. Research has shown that bifurcation ratios are controlled by basin physiographic factors and predominantly the basin relief and drainage density (Schumm, et al., 2000). However, in regions where the network geometry of streams develops without pronounced lithological or structural control, bifurcation ratios are stable showing little variation from one basin to another and may fail to confirm Horton's original suggestion that average bifurcation ratio vary from 2.0 for flat or rolling basins to 3.0 to 4.0 for mountainous or highly dissected basins (Strahler, 1957; Chorley et al,.., 1957). The values of bifurcation ratio calculated for the different order basins in the study area show stability with little variation.

Table 1: Morphometric properties of the Abione River Basin

\begin{tabular}{|c|c|c|c|c|c|c|c|c|}
\hline Order (U) & $\begin{array}{l}\text { Stream } \\
\text { Number } \\
(\mathrm{Nu})\end{array}$ & $\begin{array}{c}\text { Stream } \\
\text { Length (Lu) } \\
\mathrm{km}\end{array}$ & $\begin{array}{l}\text { Average } \\
\text { Stream length } \\
\text { (lu) } \mathrm{km}\end{array}$ & $\begin{array}{l}\text { Bifurcation } \\
\text { Ratio (Rb) }\end{array}$ & $\begin{array}{l}\text { Basin } \\
\text { area(A) } \\
\mathrm{km}\end{array}$ & $\begin{array}{l}\text { Circularity } \\
\text { ratio }\end{array}$ & $\begin{array}{l}\text { Compactness } \\
\text { coefficient }\end{array}$ & $\begin{array}{l}\text { Stream } \\
\text { Density }\end{array}$ \\
\hline 1 & 2869 & 2359 & 0.82 & 4.1 & 2164 & 0.24 & 2.0 & 1.32 \\
\hline 2 & 706 & 974 & 1.37 & 4.5 & 2265.6 & 0.25 & 1.2 & 0.31 \\
\hline 3 & 158 & 592 & 3.7 & 4.2 & 2417.6 & 0.26 & 1.9 & 0.065 \\
\hline 4 & 37 & 381 & 10.2 & 3.7 & 2610.2 & 0.29 & 1.85 & 0.014 \\
\hline 5 & 9 & 192 & 21.3 & 3 & 2836.4 & 0.31 & 1.8 & 0.0031 \\
\hline 6 & 2 & 129 & 64.5 & 1 & 3078.4 & 0.34 & 1.7 & 0.0006 \\
\hline \multirow[t]{2}{*}{7} & 1 & 102 & 102 & 0 & 3354.4 & 0.37 & 1.64 & 0 \\
\hline & $\mathrm{Nu}=3782$ & $\begin{array}{l}\mathrm{Lu} \\
4729 \mathrm{~km}\end{array}$ & & $\begin{array}{l}\text { Average Rb } \\
=2.91\end{array}$ & & $\begin{array}{l}- \\
x \mathrm{Rc}=0.29\end{array}$ & $\begin{array}{l}- \\
x_{\mathrm{Cm}}=1.72\end{array}$ & $F s=1.71$ \\
\hline
\end{tabular}

This suggests that there are little or no structural or lithological controls on the evolution and development of stream networks of the Aboine drainage basin. This also confirms the observation by Ebisemiju (1985) that there is no significant structural control on the evolution of the drainage network and surface landform of the Sandstone dominated areas of South-eastern Nigeria of which the study area forms a part. The area of the basin of each order (from first to seventh order basin) was calculated in such a way that the area of a higher order basin will include area(s) of the next lower order basins. In this regard, the area of the first order basin will include all the areas of the entire first order basins. The area of the second order basin on the other hand will include the areas of all the second orders with that of the first order basins, plus the inter-basin area of the first order and so on up to the seventh order basin. A law of stream composition was developed by Horton (1945) to investigate this relationship. According to Horton's law of stream area the average area of drainage basin for each of the different order tend to approximate closely to a geometrical series in which the first is the average area of first-order basin. This means that the average stream area of each order increases geometrically with increasing order and decreases number (Table 1). The Aboine drainage basin conforms well to this law.

Since our study area yielded a circularity value far from unit number, the basin shape is said to be elongated. The value of the circularity ratio for our study area is also an indication our study area produces little surface runoff. This is because runoff travels more rapidly in a circular shaped basin where surface runoff has an equidistant travel to the main discharge channel than in elongated basin. The compactness coefficient value is equal to unit when the basin shape is a perfect circle and varies from 1.198 to 2.6 in the case of an elongated basin and may exceed 3.00 for a very elongated basin. The value of compactness coefficient for the study area provides further information that the basin is elongated and hence will produce little surface runoff. 
From table 2 moisture deficit in the basin generally begins from January and lasts up to April while utilization begins from October up to December. The basin attains a field capacity from August to
September and decreases in moisture storage from October when more water is removed from the basin to meet plant water needs.

Table 2: Computed Mean Water Budget Components of the Aboine Drainage Basin (1984 -1987) (mm)

\begin{tabular}{|c|c|c|c|c|c|c|c|c|c|c|c|c|c|}
\hline & $\mathrm{J}$ & $\mathrm{F}$ & $\mathrm{M}$ & $\overline{\mathrm{A}}$ & $\mathrm{M}$ & $\mathrm{J}$ & $\mathrm{J}$ & $\overline{\mathrm{A}}$ & $\mathrm{S}$ & $\mathrm{O}$ & $\mathrm{N}$ & D & TOTAL \\
\hline P & 0 & 15.7 & 33 & 149 & 174 & 201 & 245 & 292 & 223 & 136 & 0 & 0 & 1468.7 \\
\hline ST & 0 & 0 & 0 & 7.2 & 52.3 & 93.8 & 200 & 250 & 250 & 242.1 & 110 & 0 & 1205.4 \\
\hline $\mathrm{AE}$ & 31 & 15.7 & 33 & 141.8 & 128.9 & 159.5 & 138.8 & 146.1 & 134.2 & 143.9 & 132 & 110 & 1335.7 \\
\hline DET & 86.1 & 122.2 & 114.4 & 0 & 0 & 0 & 0 & 0 & 0 & 0 & 0 & 21.3 & 344 \\
\hline
\end{tabular}

Field capacity $=\mathbf{2 5 0}$

With the knowledge of our monthly rainfall, monthly potential evapotranspiration, and runoff coefficient of our study area, monthly surface runoff of the study area was computed using equation (3). Since the amount of infiltrated rainwater in the basin was not directly measured, we consequently related the runoff coefficient of the basin with the basins soil moisture storage to give a monthly "potential moisture storage". The term potential moisture storage as used in the study represents the expected amount of rainwater which will infiltrate into the soil to recharge the groundwater storage after the effects of basin surface characteristics on the precipitated rainwater have been accounted for.The distribution of computed surface runoff values using modified Thornthwaite water balance model are shown in Table 3

Table 3 : Computed mean monthly Surface Runoff using modified THWB Model (mm) (1984-1987)

\begin{tabular}{|c|c|c|c|c|c|c|c|c|c|c|c|c|c|}
\hline & $\mathrm{J}$ & $\mathrm{F}$ & $\mathrm{M}$ & $\mathrm{A}$ & $\mathrm{M}$ & $\mathrm{J}$ & $\mathrm{J}$ & $\bar{A}$ & $S$ & $\mathrm{O}$ & $\mathrm{N}$ & $\mathrm{D}$ & Year \\
\hline $\mathrm{P}$ & 0 & 0 & 16.1 & 138 & 131 & 351 & 307 & 386 & 340 & 125 & 21 & 0 & 1815.1 \\
\hline PET & 116.6 & 137.9 & 147.4 & 144.9 & 143.9 & 134.2 & 133.5 & 133.6 & 129.2 & 138.7 & 127 & 119.1 & 1606 \\
\hline $\mathrm{St}(\mathrm{C})$ & 0 & 0 & 0 & 0 & 0 & 75.9 & 60.7 & 88.3 & 73.8 & 0 & 0 & 0 & \\
\hline $\mathrm{Q}$ & 0 & 0 & 0 & 0 & 0 & 140.9 & 112.8 & 164 & 137 & 0 & 0 & 0 & 554.7 \\
\hline
\end{tabular}

Runoff coefficient $C^{\prime}=\mathbf{0 . 3 5}$

In Table 3, monthly surface runoff of our basin is estimated as the residual of our modified water balance equation. Surface runoff reaches a peak in the month of August and decreases from the month of October due to cessation of rainfall. Adopting the hydrograph separation technique, the mean water stage of the study area was separated into surface runoff and ground water components (Table 4). As Gusti (1978) observed, when a hydrograph is separated, periods of surface runoff contributions are indicated by the parts of the water stage that produce distinct and clearly defined peaks on the hydrograph, while the leftover of the water stage are considered as the groundwater contributions which continue to feed the stream after rainfall has ceased. The months of distinct and clearly defined peaks on the graph marking the surface runoff contribution to water stage are observed from May up to October respectively. These months further coincide with the months of high rainfall values in the basin. In separating the water stage of the study area, account was made of the periods of start and end of rainfall in the study area

Table 4: Result of separated mean water stage of the Aboine Basin in meters (1984-1987)

\begin{tabular}{lllllllllllll}
\hline & J & F & M & A & M & J & J & A & S & O & N & D \\
Mean stage & 2.6 & 3.5 & 4.3 & 3.91 & 6.97 & 8.93 & 5.94 & 5.5 & 10.65 & 9.35 & 4.71 & 2.72 \\
Ground flow & 2.6 & 3.5 & 4.3 & 3.91 & 3.91 & 3.91 & 3.91 & 3.91 & 3.91 & 3.91 & 4.71 & 2.72 \\
Surface flow & 0 & 0 & 0 & 0 & 3.06 & 5.02 & 2.03 & 1.59 & 6.74 & 5.44 & 0 & 0 \\
\hline
\end{tabular}

From Table 4, surface runoff contribution include the part of stage that feeds the stream during rainfall while that of ground water flows include the part of flow which continues even after rainfall has ceased.
Groundwater contribution tends to be constant when the groundwater storage reaches its field capacity when rainfall amounts increase significantly, while runoff contribution varies with variation in rainfall 
and losses due to evapotranspiration. From our estimated groundwater flow contributions to water stage, it is now possible to estimate the monthly stream discharge values for the period of study as the sum of surface runoff and groundwater flow contributions. Meanwhile, our estimated mean monthly surface runoff contributions to discharge (calculated from our modified water balance equation) which are in millimeters were further converted to meters in the same scale of measurement as our separated groundwater contribution to stage. Estimated stream discharge values are presented in Table 5.

Table 5: Estimated stream discharge of the Aboine Drainage Basin (m) (1984-1987)

\begin{tabular}{|c|c|c|c|c|c|c|c|c|c|c|c|c|c|}
\hline & $\mathrm{J}$ & $\mathrm{F}$ & M & A & M & $\mathrm{J}$ & $\mathrm{J}$ & A & $\mathrm{S}$ & $\mathrm{O}$ & $\mathrm{N}$ & $\mathrm{D}$ & Year \\
\hline $\begin{array}{l}\text { Surface flow in } \\
\text { meters }\end{array}$ & 0 & 0 & 0 & 0 & 0 & 0.141 & 0.113 & 0.164 & 0.137 & 0 & 0 & 0 & 0.56 \\
\hline $\begin{array}{l}\text { Groundwater Flow } \\
\text { in meters }\end{array}$ & 2.6 & 3.5 & 4.3 & 3.91 & 3.91 & 3.91 & 3.91 & 3.91 & 3.91 & 3.91 & 4.71 & 2.72 & 45.2 \\
\hline $\begin{array}{l}\text { Discharge } \\
\text { converted } \\
\text { meter }\end{array}$ & 2.6 & 3.5 & 4.3 & 3.91 & 3.91 & 4.05 & 4.02 & 4.07 & 4.05 & 3.91 & 4.71 & 2.72 & 54.05 \\
\hline
\end{tabular}

Variations in monthly discharge in our study area are observed. There is a significant rise in discharge amount from May which reaches a maximum in August. Discharge value decreases from October up to the month of April due to cessation in rainwater supply as well as due to withdrawal of water from the basin to meet vegetation water needs. Comparison of calculated discharge values from stage and those of computed discharge using modified THWB balance technique was also undertaken. This is in order to test for the effectiveness of the water balance technique for appraising the water resources of ungauged basins. Stage records of our study were obtained using equation 4 (Table 6).

Table 6: Calculated discharge from stage and computed discharge from water balance (meter)

\begin{tabular}{llll}
\hline Months & $\begin{array}{l}\text { Mean stage (1984-1987) } \\
\text { Meters }\end{array}$ & $\begin{array}{l}\text { Computed discharge } \\
\text { from stage }\end{array}$ & $\begin{array}{l}\text { Computed discharge from } \\
\text { Modified THW water balance }\end{array}$ \\
\hline JAN & 2.6 & 15.04 & 2.6 \\
FEB & 3.5 & 31.63 & 3.5 \\
MARCH & 4.3 & 52.91 & 4.3 \\
APRIL & 3.91 & 41.72 & 3.91 \\
MAY & 6.97 & 177 & 3.91 \\
JUNE & 8.93 & 333.5 & 4.05 \\
JULY & 5.94 & 118.67 & 4.02 \\
AUST & 5.5 & $97 . .9$ & 4.07 \\
SEPT & 10.7 & 516.8 & 4.05 \\
OCT & 9.4 & 373.83 & 3.91 \\
NOV & 4.71 & 66.44 & 4.71 \\
DEC & 2.72 & 16.69 & 2.72 \\
\end{tabular}

From Table 6, variations can be observed between the monthly and annual values of calculated discharge from stage records and those obtained from our modified water balance model. These variations can be attributed to influence of environmental factors on the results of calculated discharge using our modified water balance method. For example, the under estimation of our computed monthly discharges using water balance model against computed discharge from water stage may have resulted in part due to the seasonal nature of vegetation growth and water demand of the basin. Vegetation water demand increases with increase in evapotranspiration over precipitation. Periods in which evapotranspiration exceeds atmospheric water supply, water supply to the basin declines and this is taken into account in our modified water balance method. On the other hand, the overestimation of monthly values of our computed discharge using the modified water balance equation over discharge computed from water stage records may also have resulted because some local environmental factors including subsurface characteristics, basin slope, and rainfall intensity etc influencing short-term discharge are not considered in our modified water balance equation.. 
Similar problem has been encountered by authors. For example, Mather (1978) attributed the underestimation of calculated runoff values of Wilmington, Delaware against the measured values of Shellpot Creek in U.S.A to some environmental factors such as interception losses and the seasonal nature of vegetation etc which are not taken into account in using the water balance technique. Furthermore, the prime components of our modified water balance include rainfall, evapotranspiration and depth of soil moisture storage. The inclusion of the runoff coefficient component in the equation only served to represent the surface characteristics of our basin influencing water entry into the soil. This however may not have represented the role slope, relief, and linear characteristics of the basin play in discharge generation.

Conclusion: Southeastern Nigeria is well drained by streams and rivers. The behaviours of these streams and rivers are of interest to a wide variety of concern, ranging from flood control, irrigation activities, public waters supply to recreation. However, the success of any water resources planning and development will depend on the availability of information on the stream discharge of characteristics of the basin. More importantly however, a major setback in undertaking hydrological studies as well as development of models for sound water resources planning and development in most drainage basins in the region is the lack of or inadequacy of hydrological data. This study focused on stream discharge modeling using the water balance technique. Stream discharge of the study area was estimated as the sum of surface runoff and groundwater flow. The various result of our computation provides information on not only the extent of environmental controls on the basin water yields but also on the extent of discharge response to basin factors. Such information are essential and provide the framework for sound planning of the water resources of the basin and thus for increased standard of living of the people of the study area especially in the absent of measured stream discharge data.

\section{REFERENCES}

Anyadike, R.N.C. (2002): Climate and Vegetation in Ofomata, G.E.K. (ed), A Survey of the Igbo Nation. Africana First Publishers. Pp.73-82.

Adejuwon, J.O., Jeje, L.K. and Ogunkoya O.O (1983). Hydrological Response patterns of some Third Order streams on the Basement Complex of Southwestern Nigeria. Hydrological Science Journal. 28(3): 377-389

Ayoade, J.O. (1988). Tropical Hydrology and Water Resources. McMillan Publishers, London

Ayoade, J.O. (1998). Hydrology and water resources in Areola, O. and Okafor, S.I. (eds.), Fifty Years of Geography in Nigeria: The Ibadan Story. Ibadan University Press, Ibadan, pp. 331-347.

Chorley, R.J., Malm, D.E and Pogorzelski, H.A. (1957). A new standard for estimating basin shape. American Journal of Science. 256: 138141.

Dike, B. U. and Nwachukwu, B.A (2003): Analysis of Nigerian Hydrometeorological Data Nigerian Journal of Technology. 22 (.1): 29-38

Eruola A. O., Ufeogbune G. C., Eruola A. A., Idowu O. A., Oluwasanya G. O. and Ede V. A (2012). Effect of Climate Change on Water Balance of Lower Ogun River Basin Hydrology for Disaster Management: Special Publication of the Nigerian Association of Hydrological Sciences, 2012 pp 360-367

Ebisemiju, F.S. (1976). Morphometric work with Nigerian topographic maps. Nigerian Geographical Journal. 19(2): 65-77.

Ebisemiju, F.S. (1985). A reduced rank model of drainage basin morphometry. Geogra-fiska Annula. 61(1-2): 66-77.

Ezemonye M.N and Emeribe C.N (2013). Appraisal of The Hydrological Potential of Ungauged Basin Using Morphometric Parameters, Ethiopian Journal of Environmental Studies and Management 6(4) 2013: 376-380

Frantar, P. Dolinar, M. and Kurnik, B. (2008). Water Balance of Slovenia,1971-2000. Environmental Agency of the Republic of Slovenia, Lyubljana, Slovenia

Gray D. M.C. (1970). Introduction to Hydrology in Gray D.M. (ed) Handbook on the Principles of Hydrology. Water Information Centre, Inc. The North Shore Atrium.

Guarnieri, P. and Pirotta, C., (2008). The response of drainage basins to the late Quaternary tectonics 
in the Sicilian side of the Messina Strait (NE Sicily). Geomorphology, 95. 260-273.

Guisti, E.V. and Lopez, M.A. (1967). Climate and Streamflow of Puerto Rico. Caribbean Journal of Science, 7: 87-93.

Horton, R.E. (1945). Erosional development and their drainage basins. Bulletin of Geological Society American. 56: 275-370.

Hugh, D. and Ayers, B.E. (1970). Basin yield in Gray, D.M. (ed.) Handbook on the Principles of Hydrology, Water Information Center Publication.

Matsuyama H, Oki T Masuda M (1994). The seasonal change of the water budget in the Congo River Basin, J. of Meteorological Society of Japan, 72(2): 281-299.

Mather, J.R. (1978). The Climatic Water Balance in Environmental Analysis. Lexington Books, Massachusetts Toronto

Morisawa, M.E. (1957). Accuracy of determination of stream length from topographic maps Transaction, American Geophysical Union, 38: 86-88

Ofomata, G.E.K. (1975). Soils in Ofomata, G.E.K. (ed.) Nigeria in Maps: Eastern States, Ethiope Press, Benin City: 35-37

Orajaka, S.O. (1975). Geology, in Ofomata, G.E.K. (ed.) Nigeria in Maps: Eastern States, Ethiope Press, Benin City: 5-7

Pohle1, H. Koch2, and U. Gr"unewald1 (2012). Potential climate change impacts on the water balance of subcatchments of the River Spree, Germany Adv. Geosci., 32: 49-53

Rantz, S.E (1971). Suggested criteria for hydrologic design of storm-drainage facilities in the San Francisco Bay Region, California, U.S Geological Survey, Open File Report, California

Schumm, S.A., Dumont, J.F. and Holbrook, J.M., (2000). Active tectonics and alluvial rivers, Cambridge University Press, Cambridge, p.401.
Sobowale A., Adewumi J. K., Otun J. A., Adie D. B. (2010). Water resources potentials of Hadejia River Sub-catchment of Komadugu Yobe River Basin in Nigeria Agric Eng Int: CIGR Journal 12(2) 1-6

Sule, B.F, Salami, A.W, Bilewu, S.O, Adeleke, O.O and 3Ajimotokan, H.A (2011). Hydrology of River Oyun and Hydropower Potential of Unilorin Dam, Ilorin, Kwara State, Nigeria New York Science Journal, 4(1): 69-78

Suresh, R., (2000), Soil and water conservation engineering 3rd Ed. 24, Watershed concept and management, pp.785-813.

Straher A.N. (1957). Quantitative analysis of watershed geomorphology. Transactions of the American Geophysical Union..38: 279-300.

Strahler, A.N (1953). Revision of Horton's quantitative factors in erosional terrain. Transactions of American Geophysical union. . 33(2) 34-41.

Strahler, A.N. (1952). Dynamic basis of geomorphology. Geophysical Society of American Bulletin. 63(9): 923-938.

Straher A.N. (1957). Quantitative analysis of watershed geomorphology. Transactions of the American Geophysical Union. 38: 279-300.

Thornthwaite, C.W. and Mather, J.R. (1955). The water balance. Publication of Climatological Lab. Climatological Drexel Institute Technology. Vol. 8(1): 1-104.

Wharton G. and Tomlinson J.J (1999). Flood discharge estimation from river channel dimensions: results of applications in Java, Burundi, Ghana and Tanzania. Hydrological Sciences-Journal-des Sciences Hydrologiques, 44(1):97-111

Xu, C.Y. and Singh, V.P. (1998). A review on monthly water balance models for water resources investigations. Water Resources Management. 12: 37-50. 